\title{
Determination Model of Suitable Coastal Transit-Oriented Development Location, Case Study: Paotere, Makassar
}

\author{
Andi Bachtiar Arief ${ }^{1}$, Ananto Yudono ${ }^{1}$, Arifuddin Akil ${ }^{1}$, Isran Ramli ${ }^{2}$ \& Amran Rahim ${ }^{3}$ \\ ${ }^{1}$ Architecture Department of Hasanuddin University, Makassar, Indonesia \\ ${ }^{2}$ Civil Engineering Department of Hasanuddin University, Makassar, Indonesia \\ ${ }^{3}$ Mathematics and Natural Science Department of Hasanuddin University, Makassar, Indonesia \\ Correspondence: Andi Bachtiar Arief, Architecture Department of Hasanuddin University, Makassar, Indonesia. \\ Tel: 62-812-4175-0926. E-mail: andibachtiararief@gmail.com
}

Received: April 16, 2017

doi:10.5539/jsd.v10n4p31
Accepted: May 11, $2017 \quad$ Online Published: July 30, 2017

URL: https://doi.org/10.5539/jsd.v10n4p31

\begin{abstract}
Commuter and local society, the users of Paotere local port who took round trip to small islands and other island as well, experienced redundancy of cost, time and travel distance in fulfilling their whole needs at the shore of Makassar. Traveling by using motorized vehicle at the shore of Makassar was taken due to the unavailability of needed goods in the port and its neighborhood within radius 500 meters. This research is aimed at establishing determination model of suitable location for spatial planning of coastal Transit-Oriented Development (TOD) in order to eliminate redundancy of cost, time and travel distance. It applied expert system and spatial analysis method based on geographic information system (GIS). The result showed that the most suitable location for coastal TOD development was in local Port and its neighborhood, it was at some grids, 581-585 and 540-542 within walking radius. Used determination model was determination in which, relied on highest value of the location with supports from its neighborhood location as well and the correlation among; certainty factor, commuter's activity and local society.
\end{abstract}

Keywords: expert system, GIS, mixture analysis, spatial analysis

\section{Introduction}

\subsection{Introduce the Problem}

Commuter had to travel to Makassar shore for fulfilling their needs as they were not available in the port area and its neighborhood within radius 500 meters from port (J.Stepner, 1992) dan (Ngo, 2012). Those, related to basic needs and business materials are to be used at the small islands and other (Lester, 1990; Maslow, 1943). Basic needs and business materials could be found at traditional market, retail, shop, ware house, gas station and other public amenities. Until today the redundancy of cost, time and travel distance of commuter and local society keeps happening and remains unsolved. In fulfilling the basic needs of commuter, it is supposed to be sustainable in which it does not emerge problem and damage for another party and next generation (Abdullah \& Pang, 2016).

Those mentioned public facilities could be reached, using motorized vehicle; motorcycle, motor rickshaw, taxi, truck, container or private one. The motorized one creates pollution, more expensive cost and tends to cause traffic congestion and accident which are harmful for commuter and local society (Wey, 2015). The use of motorized vehicle are supposed to be minimalized, optimized and integrated with the use of massive public transportation, cycling and walking (Rahul \& Verma, 2013).

Growing number of motorized vehicle, is the choice of commuter and local society since it is more flexible, higher accessibility, and could be used every time to reach unavailable public places around the port as transit location (Davies \& Weston, 2015) and (Nur, Samang, Ramli, \& Hamid, 2016). They prefer using motorized vehicle or rented even though they are more expensive, owing to unavailability of massive public transportation to all destined locations in fulfilling their needs. To reduce the intake of that vehicle and to increase walk accessibility, it is urgent to develop spatial planning of coastal transit-oriented development (TOD), integrated with transportation (Rahul \& Verma, 2013). 
Walking might be interesting when side walk or pedestrian route exists by prioritizing; comfortability, safety, easiness in mobility and shortest travel time (Mateo-Babiano, 2016). Walking to work place, residential and other public amenities actually supports healthy life pattern and sustainable coastal TOD (Litman, 2014). However, walking is left behind day by day as it is much easier to have private vehicle (Bruce, 2012). Coastal TOD development could eliminate urban sprawl and various redundancies, for instance, time, cost and travel distance experienced by commuter and local society since the basic needs have been able to be fulfilled around the port within walking radius (Zakaria \& Ujang, 2015).

The aims of this research: 1) establish determination model of coastal TOD development around local port, Makassar, 2) find the most suitable location for coastal TOD development in the local port and its neighborhood, 3) eliminate redundancy of time, cost and travel distance of commuter and local society to fulfill basic needs and others within radius 500 meters around local port.

Commuter from port to small islands around Makassar traveled through several vehicles; speed boat, traditional ship known as phinisi, even though their departure and arrirval schedule are not certain (Chakrabarti, 2015). The travel purpose is various, for instance, working as fisher, seller/businessman, civil servant, visiting relatives or recreational activity. Motor boat from local port carries comestibles, food, clean water, drinking water, building material, tools and engines, fuel and liquid petroleum gas (LPG) and other stuffs (Maslow, 1943; Noltemeyer, Bush, Patton, \& Bergen, 2012). Loading goods activity from and onto vessel intra islands everyday also truck and container coming and going to the port, taking effect on the smoothness of traffic current on the road. Besides, road capacity, traffic volume, traffic current management and vehicle's speed also affect it (P.Green, S.Heywood, \& Navarro, 2016).

Commuter from the shore, heading to Paotere port generally cycling, riding motorcycle or driving private car, consequently, it contributed to traffic congestion and accident (Davies \& Weston, 2015). Although it is more expensive and pollutive, commuter from small islands and others who wanted to shop at traditional market, gas station, workshop, industry, relatives and shopping center usually took motor rickshaw, taxi and or private car ( $\mathrm{Lu}, \mathrm{Zhu}, \mathrm{Li}$, Singh, \& Nozaki, 2016). Those vehicles were used, as the destination is not located within walking radius furthermore, bus rapid transit (BRT), mass rapid transit (MRT) or light rapid transit (LRT) are not provided (P.Green et al., 2016). Hence, Infrastructure development of public service; traditional market, shopping centers, culinary, office and residential port as transit location is urgent to be constructed (Noltemeyer et al., 2012) (Noltemeyer et al., 2012).

Local port area and the neighborhood are dominated by residential building, there are no traditional market, shopping centers and gas station within walking radius, in turn, the commuter is dependent on motor rickshaw and motorcycle (Jain, 2015). Shopping centers along the road around the port are not completed with plenty parking area, therefore, the shoulder and road bed sometimes get disturbance, hence, travel distance of the road users becomes longer, fuel operational cost gets more redundant as well as the rise of air pollution through motorized vehicle emission (Quinn, Adams, Dix, \& Bull, 1998).

Disturbed traffic as the result of vehicle chaotical on double route road is caused by both the truck or container carrying goods from and to port and parked vehicle at the shoulder or road bed (Arnott \& Inci, 2006). This matter provokes; noisy, uncomfortability, redundancy of fuel, a rise of operational cost, vehicle maintenance and air pollution as well (Khootdee, Singhirunnusorn, \& Sahachaisaeree, 2012). It needs strong commitment from government to be able to eliminate and establish them in accordance with urban transportation principle (Balachandran et al., 2014).

Establishing urban transportation and TOD development object to prevent traffic congestion and accident, obtain time efficiency, minimize fuel intake, reduce noise and pollution, create more orderly road users, smoother and better traffic, be more beneficial to physical and mental health, reduce the risk of having disease, be healthier and stay alive longer (Khootdee et al., 2012). Traffic congestion and traffic accident rise transportation cost and vehicle operational, travel distance for 2-3 times longer, besides, they reduce work productivity by losing working time about 33,3\% within 10 days (Mpogole \& Msangi, 2016).

Commuter hopes, spatial planning development of local port areas could be compact, diverse, dense, comfortable, meet the need of commuter and society, eco-friendly and sustainable (Khootdee et al., 2012) and (Hasibuan, Soemardi, Koestoer, \& Moersidik, 2014). In order to fulfill all the needs of commuter within walking radius in the port and its vicinity efficiently and in less redundant way, it is important to develop sptatial planning based on potency, problem and principle of TOD (Vale, 2015).

This determination model of coastal TOD development location is suitable with certainty factors from expert system, spatial planning potential also commuter's and local society. It is implemented through partnership 
among several parties; government, entrepreneurs, NGO and society, in turn, among pedestrian, land use and public amenities both at the shore or sea mass transit could be integrated (Wey, 2015), (Renne, 2008). Mass transit should be available in well-scheduled, connected, on time, safe and reliable (Chakrabarti, 2015) (Jin, Shuxin Wang, Jianjun Jiao, \& Jiannan, 2013), be able to be accessed by walking or cycling comfortably from and to residential, working place, shopping centers, traditional market and other public services within local port and its surroundings, (Cervero \& Guerra, 2013), (Litman, 2014), and (Feudo, 2014).

\subsection{Explore Importance of the Problem}

Paotere local port is used as transit location for commuter from and to islands around Makassar and others. They are ship crews, fishery, housewives, college student, civil servant, employee and businessman. They have activity related to their each need. The problem is they do their activities at Makassar shore since their basic needs are not available in those islands. They must travel despite of farther and longer trip, higher cost and sometimes uncomfortable on the sea due to bad weather and west season. Commuter from small islands are supposed to be able to fulfill their basic needs without going to Makassar shore, in order to prevent undegradable environment supporting elements when the infrastructure of goods services in those islands provided (Elrayies, 2016).

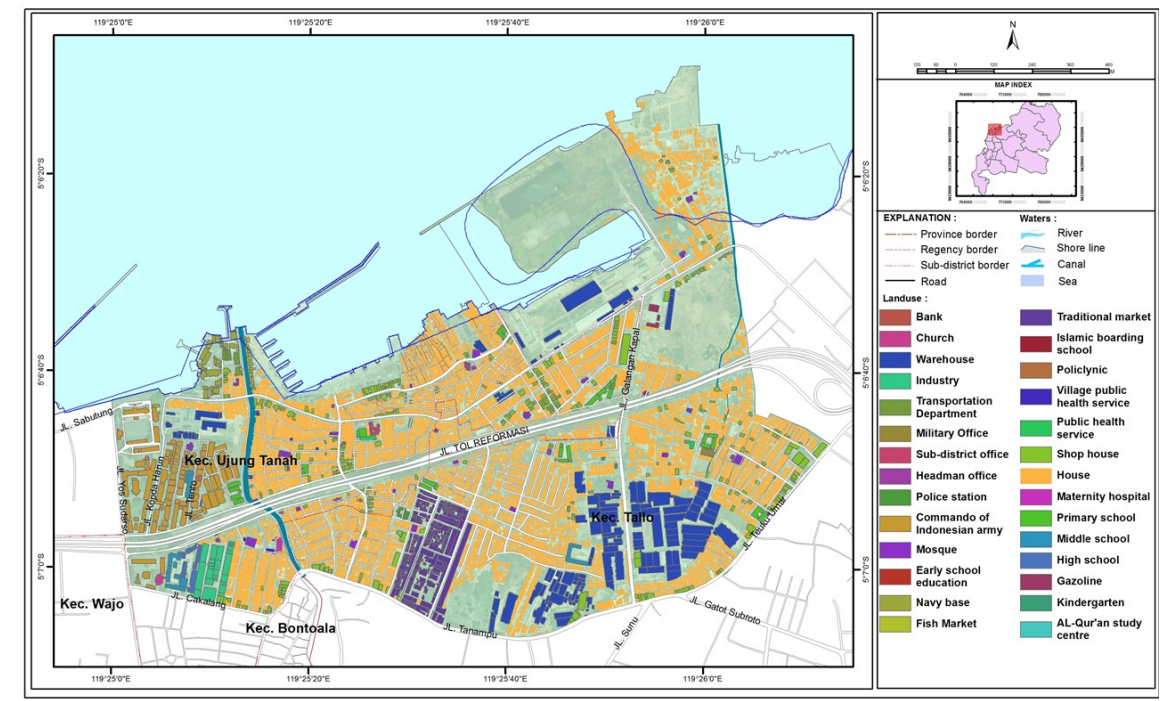

Figure 1. Map of existing land use of research location, local port and the neighborhood

Land situated at the vicinity of local port, commonly dominated as settlement, residential, shop house, praying spot, education, health and office. Gas station and traditional market could be reached using private vehicle, motorcycle, motor rickshaw, or rickshaw, it brings more transportation cost. Land use around local port and the neighborhood shown at the Figure 1. Building density within radius 500 meters at the research location remains less dense (25\%-50\%) in total. Generally, the buildings are with 1-2 floors and the density level especially in the port is $<25 \%$ or not dense. It gives chance to be developed vertically: green vertical building; vertical quay, tenement house (multilevel house), shopping centers, rental office, gas station and traditional, supported with complete public infrastructure building density can be seen at Figure 2 . 


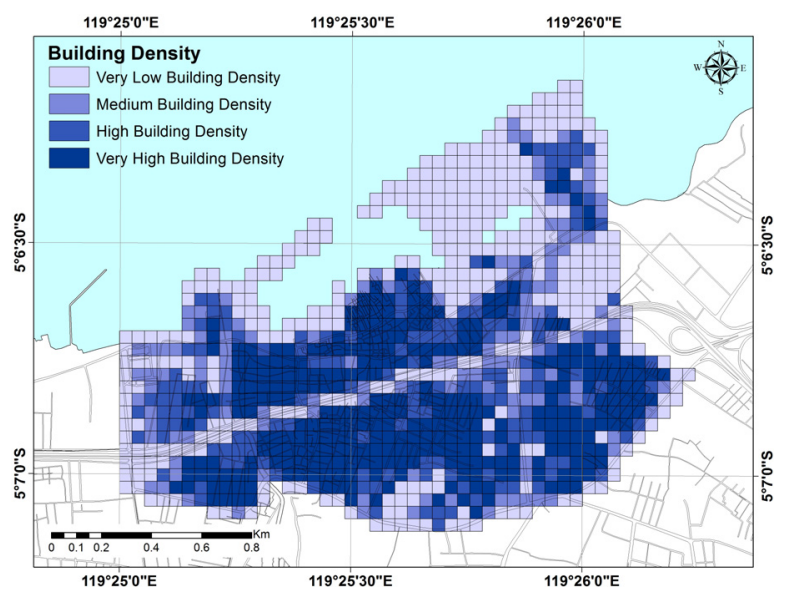

Figure 2. Building density map

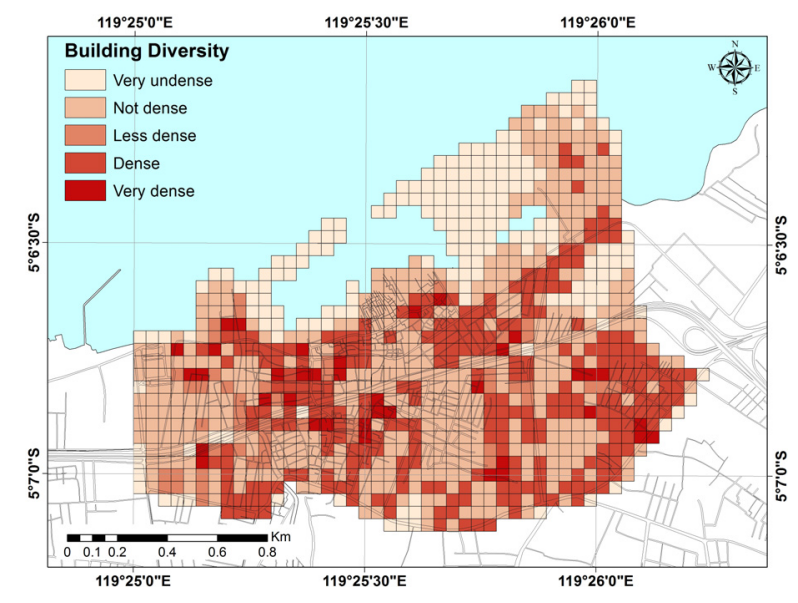

Figure 3. Building diversity map

Besides, high diversity building among residential, commercial and office or working place, is one of the characteristics of TOD in which should be found in the port neighborhood as transit location. That diversity level in the port and its surrounding is $<25 \%$ or not diverse, thus, it is very potential to be developed to be able the commuter to eliminate redundancy of transportation cost in fulfilling all their basic needs at Makassar shore. Building diversity level is shown at Figure 3. The lack of diversity and low building density demonstrate the existence of urban sprawl, thus creating environment degradation and unsustainable development (Soltani, Hosseinpour, \& Hajizadeh, 2017). This diversity is categorized into 4 categories; very diverse with certainty factor $(\mathrm{CF})=6$, diverse $\mathrm{CF}=5$, less diverse $\mathrm{CF}=4$ and not diverse $\mathrm{CF}=3$.

Port and parking area only have few trees without park and another supporting element as waterfront city. Hence, commuter feels hot, barren and less comfortable in the port area. Increasing the number of green space could reduce temperature acting as dust and noise filter, beautify and add interesting value of the port and the neighborhood [5]. Related to tropical climate, hot weather, urban sprawl and unwell planned building design, create untidiness or slum and uncomfortable (Elrayies, 2016).

\section{Methods}

It applied expert system spatial analysis based on geographic information system (GIS) through ArcGIS, ArcView. Microsoft Excel, Fortran and Quantum GIS application. Figure 4 is Expert System with 14 factors/rules (1 rule TOD impossible area and 13 rules TOD development restraint area). 


\begin{tabular}{|c|c|c|c|}
\hline \multicolumn{3}{|c|}{\begin{tabular}{l|l} 
Rule 1 & Military Navy \\
\end{tabular}} & Other \\
\hline \multicolumn{2}{|c|}{ TOD Impossible Area } & TOD Development Restraint Area & Other \\
\hline \\
\hline \multirow{4}{*}{$\mathbf{Y}$} & \multicolumn{3}{|c|}{ Rule 2. High accessibility area for crossed by road } \\
\hline & \multicolumn{2}{|c|}{ Arterial road $(\mathrm{CF}=5)$, Collector road $(\mathrm{CF}=4)$, Local road $(\mathrm{CF}=3)$} & Other \\
\hline & \multicolumn{3}{|c|}{ Rule 3. Building density around port (local port or marine tourism port) } \\
\hline & \multicolumn{2}{|c|}{$<25 \% \mathrm{CF}=5,25 \%-50 \% \mathrm{CF}=4,51 \%-75 \% \mathrm{CF}=3,>75 \% \mathrm{CF}=2$} & Other \\
\hline i & \multicolumn{3}{|c|}{ Rule 4. Bulding diversity near port area (radius $600 \mathrm{~m}$ ) } \\
\hline i & \multicolumn{2}{|c|}{$\begin{array}{l}\text { Combining: commercial-residental-office }(\mathrm{CF}=5) \text {, commercial-residental }(\mathrm{CF}=4) \text {, } \\
\text { commercial-office }(\mathrm{CF}=3) \text {, commercial only }(\mathrm{CF}=2)\end{array}$} & Other \\
\hline i & \multicolumn{3}{|c|}{ Rule 5. Distance from port to Residence } \\
\hline i & \multicolumn{2}{|c|}{$<250 \mathrm{~m}(\mathrm{CF}=5), 250 \mathrm{~m}-500 \mathrm{~m}(\mathrm{CF}=4), 500 \mathrm{~m}-1000 \mathrm{~m}(\mathrm{CF}=3),>1000 \mathrm{~m}(\mathrm{CF}=2)$} & Other \\
\hline ! & \multicolumn{3}{|c|}{ Rule 6. Distance from port to store } \\
\hline i & \multicolumn{2}{|c|}{$<250 \mathrm{~m}(\mathrm{CF}=5), 250 \mathrm{~m}-500 \mathrm{~m}(\mathrm{CF}=4), 500 \mathrm{~m}-1000 \mathrm{~m}(\mathrm{CF}=3),>1000 \mathrm{~m}(\mathrm{CF}=2)$} & Other \\
\hline I & \multicolumn{3}{|c|}{ Rule 7. Distance from port to traditional market } \\
\hline ! & \multicolumn{2}{|c|}{$<250 \mathrm{~m}(\mathrm{CF}=5), 250 \mathrm{~m}-500 \mathrm{~m}(\mathrm{CF}=4), 500 \mathrm{~m}-1000 \mathrm{~m}(\mathrm{CF}=3),>1000 \mathrm{~m}(\mathrm{CF}=2)$} & Other \\
\hline i & \multicolumn{3}{|c|}{ Rule 8. Distance from port to school } \\
\hline | & \multicolumn{2}{|c|}{$<250 \mathrm{~m}(\mathrm{CF}=5), 250 \mathrm{~m}-500 \mathrm{~m}(\mathrm{CF}=4), 500 \mathrm{~m}-1000 \mathrm{~m}(\mathrm{CF}=3),>1000 \mathrm{~m}(\mathrm{CF}=2)$} & Other \\
\hline & \multicolumn{3}{|c|}{ Rule 9. Distance from port to offices } \\
\hline ! & \multicolumn{2}{|c|}{$<250 \mathrm{~m}(\mathrm{CF}=5), 250 \mathrm{~m}-500 \mathrm{~m}(\mathrm{CF}=4), 500 \mathrm{~m}-1000 \mathrm{~m}(\mathrm{CF}=3),>1000 \mathrm{~m}(\mathrm{CF}=2)$} & Other \\
\hline 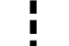 & \multicolumn{3}{|c|}{ Rule 10. Distance from port to public health or hospital } \\
\hline 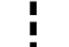 & \multicolumn{2}{|c|}{$<250 \mathrm{~m}(\mathrm{CF}=5), 250 \mathrm{~m}-500 \mathrm{~m}(\mathrm{CF}=4), 500 \mathrm{~m}-1000 \mathrm{~m}(\mathrm{CF}=3),>1000 \mathrm{~m}(\mathrm{CF}=2)$} & Other \\
\hline 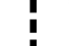 & \multicolumn{3}{|c|}{ Rule 11. Distance from port to apotek/drug store } \\
\hline 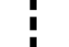 & \multicolumn{2}{|c|}{$<250 \mathrm{~m}(\mathrm{CF}=5), 250 \mathrm{~m}-500 \mathrm{~m}(\mathrm{CF}=4), 500 \mathrm{~m}-1000 \mathrm{~m}(\mathrm{CF}=3),>1000 \mathrm{~m}(\mathrm{CF}=2)$} & Other \\
\hline 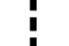 & \multicolumn{3}{|c|}{ Rule 12. Distance from port to mosque, church } \\
\hline 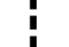 & \multicolumn{2}{|c|}{$<250 \mathrm{~m}(\mathrm{CF}=5), 250 \mathrm{~m}-500 \mathrm{~m}(\mathrm{CF}=4), 500 \mathrm{~m}-1000 \mathrm{~m}(\mathrm{CF}=3),>1000 \mathrm{~m}(\mathrm{CF}=2)$} & Other \\
\hline I & \multicolumn{3}{|c|}{ Rule 13. Distance from port to gazoline } \\
\hline I & \multicolumn{2}{|c|}{$<250 \mathrm{~m}(\mathrm{CF}=5), 250 \mathrm{~m}-500 \mathrm{~m}(\mathrm{CF}=4), 500 \mathrm{~m}-1000 \mathrm{~m}(\mathrm{CF}=3),>1000 \mathrm{~m}(\mathrm{CF}=2)$} & Other \\
\hline 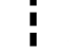 & \multicolumn{3}{|c|}{ Rule 14. Distance from port to bank } \\
\hline ! & \multicolumn{2}{|c|}{$<250 \mathrm{~m}(\mathrm{CF}=5), 250 \mathrm{~m}-500 \mathrm{~m}(\mathrm{CF}=4), 500 \mathrm{~m}-1000 \mathrm{~m}(\mathrm{CF}=3),>1000 \mathrm{~m}(\mathrm{CF}=2)$} & Other \\
\hline & & Rank of TOD potential & \\
\hline & by political a & TOD D & \\
\hline
\end{tabular}

Figure 4. Expert System of Makassar Paotere Local Port

Data of commuter was obtained at local port through direct interview randomly related to identity, origin, destination, purpose, transportation mode, time, cost, and expectation. Land use data was taken by survey and direct observation at the port and its neighborhood within radius about 500-2000 meters from local port. Google earth map is a reference of survey and observation in August 2016. The data was presented into digitation map with grid 50 meters x 50 meters. These Grids consist of main grid and neighbor grid. Commonly, it is based on lateral (rock contiguity), angle (bishop contiguity) and the mix of the two-(queen contiguity) (Briggs, 2007). These 14 factors are described in 52 Certainty Factors (CF) values, as shown at Table 1. 
Table 1 . The set up the certainty factor $(\mathrm{CF})$ of local port

\begin{tabular}{|c|c|c|c|c|}
\hline No & Factor & Category & $\mathrm{CF}$ & Code \\
\hline 1 & Military Navy & Military Navy & $\mathrm{Y} / \mathrm{N}$ & PS \\
\hline \multirow[t]{3}{*}{2} & \multirow{3}{*}{$\begin{array}{l}\text { High accessibility } \\
\text { area for crossed by } \\
\text { road }\end{array}$} & Arterial road & 6 & AR \\
\hline & & Collector road & 5 & $\mathrm{CR}$ \\
\hline & & Local road & 4 & LR \\
\hline \multirow[t]{4}{*}{3} & \multirow[t]{4}{*}{ Building density } & $<25 \%$ (very low) & 6 & \multirow{4}{*}{$\mathrm{BD}$} \\
\hline & & $25-50 \%$ (low) & 5 & \\
\hline & & $51-75 \%$ (high) & 4 & \\
\hline & & $>75 \%$ (very high) & 3 & \\
\hline \multirow[t]{4}{*}{4} & \multirow{4}{*}{$\begin{array}{l}\text { Building diversity } \\
\text { near port area (radius } \\
600 \mathrm{~m} \text { ) }\end{array}$} & $\begin{array}{l}\text { Combining commercial, residential, and office } \\
\text { (more diverse) }\end{array}$ & 6 & \\
\hline & & Combining commercial, and residential (diverse) & 5 & DV \\
\hline & & Combining commercial, and office (less diverse) & 4 & \\
\hline & & Commercial only (not diverse) & 3 & \\
\hline \multirow[t]{4}{*}{5} & \multirow{4}{*}{$\begin{array}{l}\text { Distance to: } \\
\text { residence (RS), store } \\
(\mathrm{ST}), \text { traditional } \\
\text { market (TM), school } \\
(\mathrm{SH}), \text { offices (OF), }\end{array}$} & $<250$ m (very near) & 6 & $\mathrm{RS}$, \\
\hline & & $250-500 \mathrm{~m}$ (near) & 5 & ST, \\
\hline & & $500-1000 \mathrm{~m}$ (far) & 4 & TM,SH, \\
\hline & & $>1000$ m (very far) & 3 & OF \\
\hline \multirow[t]{4}{*}{6} & \multirow{4}{*}{$\begin{array}{l}\text { Distance to hospital } \\
\text { (HO), drug store } \\
\text { (DS), mosque, } \\
\text { church (MC), } \\
\text { gasoline (GZ), bank } \\
\text { (BK) }\end{array}$} & $<250$ m (very near) & 6 & $\mathrm{HO}$ \\
\hline & & $250-500 \mathrm{~m}$ (near) & 5 & $\mathrm{DS}, \mathrm{MC}$, \\
\hline & & 500-1000m (far) & 4 & $\mathrm{GZ}$ \\
\hline & & >1000 m (very far) & 3 & $\mathrm{BK}$ \\
\hline
\end{tabular}

Based on data processing through ArcGIS, ArcView, Microsoft Excel, Fortran and Quantum GIS application, selected TOD or grid location was examined further applying spatial analysis method. Potential main grid with the highest value based on its neighbor grid value is considered as the most suitable grid to be developed as coastal TOD and this is actually the purpose spatial analysis designed for. Correlation between main grid and its neighbor grid is stated in Moran's Index (Briggs, 2007), with equation (1) and (2).

$$
I=\frac{N \sum_{\mathrm{i}=1}^{\mathrm{n}} \sum_{\mathrm{j}=1}^{\mathrm{n}} \mathrm{w}_{\mathrm{ij}}\left(\mathrm{x}_{\mathrm{i}}-\overline{\mathrm{x}}\right)\left(\mathrm{x}_{\mathrm{j}}-\overline{\mathrm{x}}\right)}{\left(\sum_{\mathrm{i}=1}^{\mathrm{n}} \sum_{\mathrm{j}=1}^{\mathrm{n}} \mathrm{w}_{\mathrm{ij}}\right) \sum_{\mathrm{i}=1}^{\mathrm{n}}\left(\mathrm{x}_{\mathrm{i}}-\overline{\mathrm{x}}\right)^{2}}
$$

where $I$ is Moran's index, $N$ is number of grid, $x_{i}$ is variable value at grid $i . \bar{x}$ is mean of $x_{i}$ value and $w_{i j}$ is the weight index of grid $i$ and $j$

$$
C=\frac{[N-1] \sum_{i=1}^{n} \sum_{j=1}^{n} w_{i j}\left(x_{i}-x_{j}\right)^{2}}{2\left(\sum_{i=1}^{n} \sum_{j=1}^{n} w_{i j}\left(x_{i}-\bar{x}\right)^{2}\right)}
$$

where $C$ is contiguity, $N$ is number of grid, $x_{i}$ is variable value at grid $i . \bar{x}$ is mean of $x_{i}$ value and $W_{i j}$ is the weight index of grid $i$ and $j$.

Spatial dispersion pattern type consists of three : 1) random, if every spot doesn't affect one another and it 
happens in each location, 2) clustered, if there are many spots get closed and affect one another 3) uniform or regular, if all the points or spot are away from one another and they don't get affected one another as well. Moran index value ranges from -1 until +1 . If Moran index $-1 /(n-1)$ is closed to 0 , it means no correlation, the value is above $-1 /(\mathrm{n}-1)$ and closed to +1 , it means clustered pattern while value below $-1(/ \mathrm{n}-1)$ and closed to -1 , it means it tends to be dispersed, if it is closed to -1 or +1 , it means it has high correlation (Briggs, 2007).

Observation location demonstrates positive spatial correlation if I > E (I). E=Expectation. Closed grids generally have high similarity level or similar character. The location also indicates homogenous spatial correlation or diverse if $\mathrm{I}<\mathrm{E}$ (I) and the closed grids tend to have different characteristic. Grid in that location does not have spatial correlation if I=E (I). Mean value from two grids is referred as Moran's I value. Moran's I means that main grid value toward its neighbor grid value is valuable if it is -1 until +1 . If it is closed to -1 and if it means the main grid has low (L) in contrast, its neighbor grid has high $(\mathrm{H})$ and vice versa. If it is closed to 0 , it means high-high (HH) and low-low (LL) are even with high-low (HL) and low-high (LH), it is considered as random. If it is closed to +1 , it means $\mathrm{HH}$ and LL have dominant character which is similar with the neighbor (Briggs, 2007).

Spatial association (SA) or grid grouping pattern has positive spatial correlation if it is at LL or HH. When it is at quadrant $\mathrm{HL}$ or LH, the spatial correlation said negative. To determine accuracy or main grid significance with its neighbor positively, LISA or Local Indicators of Spatial Association was applied. It is relevant with grid percentage dispersed in group. It is completed with significance test for each to finally find selected significant grid. Geary's C method (Contiguity) can measure spatial correlation apart from Moran Index. Geary's C Ratio has scale ranging from $0-2$. When it is 0 , it means positive or clustered. When it 1 ,it means random and 2 means negative or dispersed with equation (Briggs, 2007).

\section{Results and Discussion}

Moran's I Scatter Plots result shown by 957 grids at 4 quadrants HH, HL, LL, and LH was $1=0,714711$ at scale $0-1$. There was very strong positive spatial correlation between main grid and its neighbor.

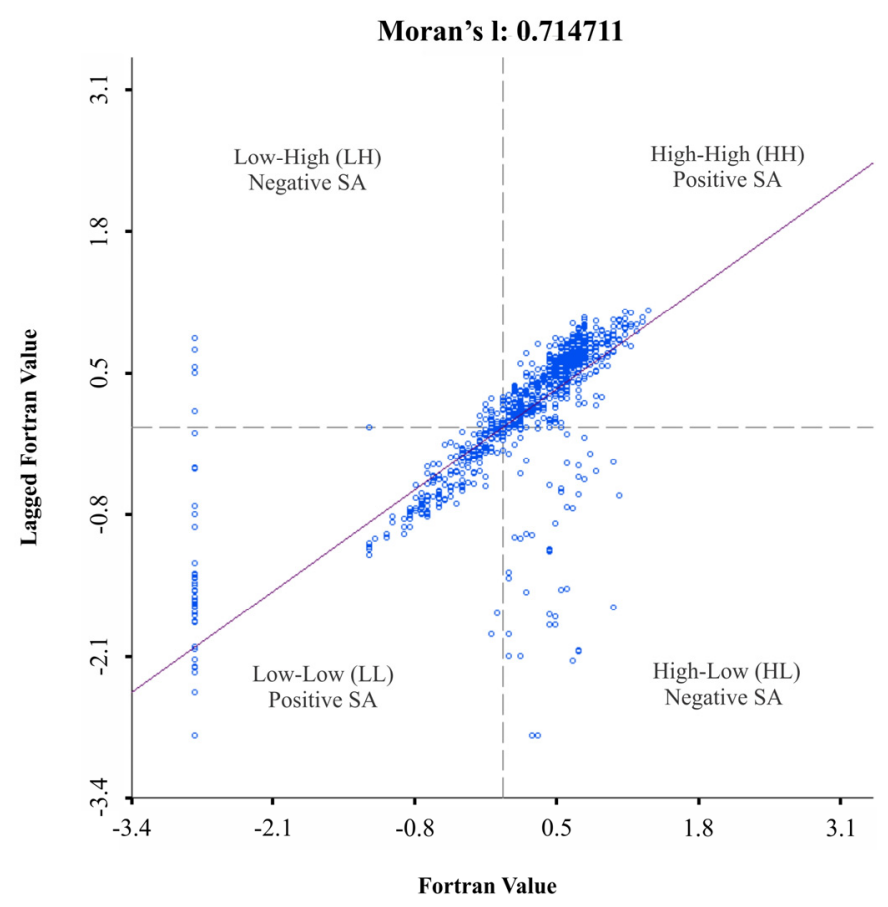

Figure 5. Moran's Index

TOD development also depends on political policy and fund availability. When there was military area, it could not be developed as coastal TOD. Data processing through Fortran resulted CF value for 957 grids. The highest value was 79 as a location and it was at grid 584 and 585, followed by grid 542 and 581 with value $=78$, grid 541,582 with value $=77$ and grid 540, 543, 625, 932 with value $=76$ as shown at Table 2. 
Table 2. Grid Priority grids for coastal TOD at local port areas and the neighborhood

\begin{tabular}{|c|c|c|c|c|c|}
\hline Grid & $\mathrm{X}$ axis & $\mathrm{Y}$ axis & Value & $\begin{array}{l}\text { Development } \\
\text { Priority }\end{array}$ & Explanation \\
\hline 584 & 19 & 26 & \multirow{2}{*}{79} & \multirow{10}{*}{ I } & \multirow{10}{*}{$\begin{array}{l}\text { Grid location for coastal TOD } \\
\text { development within radius about } 500 \\
\text { meters was situated around: } \\
\text { - } \quad \text { Straight artery road of public port to } \\
\text { arterial road. } \\
\text { - } \quad \text { House/citizen residential/ settlement } \\
\text { - } \quad \text { Traditional market } \\
\text { - } \quad \text { Facilities for health and worship, } \\
\text { education and banking. }\end{array}$} \\
\hline 585 & 20 & 26 & & & \\
\hline 542 & 22 & 25 & \multirow{2}{*}{78} & & \\
\hline 581 & 16 & 26 & & & \\
\hline 541 & 21 & 25 & \multirow{2}{*}{77} & & \\
\hline 582 & 17 & 26 & & & \\
\hline 540 & 20 & 25 & \multirow{4}{*}{76} & & \\
\hline 543 & 23 & 25 & & & \\
\hline 625 & 15 & 27 & & & \\
\hline 932 & 10 & 35 & & & \\
\hline 461 & 31 & 23 & 74 & \multirow{12}{*}{ II } & \multirow{12}{*}{$\begin{array}{l}\text { Grid location for coastal TOD } \\
\text { development within radius about } 1000 \\
\text { meters was situated around: } \\
\text { - Straight artery road of public port to } \\
\text { arterial road. } \\
\text { - House/citizen residential/settlement } \\
\text { - } \quad \text { Facilities for health, worship, } \\
\text { warehouse, education, shop house, } \\
\text { and culinary. }\end{array}$} \\
\hline 421 & 33 & 22 & \multirow{4}{*}{73} & & \\
\hline 458 & 28 & 23 & & & \\
\hline 459 & 29 & 23 & & & \\
\hline 506 & 22 & 24 & & & \\
\hline 460 & 30 & 23 & \multirow{2}{*}{72} & & \\
\hline 552 & 32 & 25 & & & \\
\hline 462 & 32 & 23 & \multirow{3}{*}{71} & & \\
\hline 597 & 32 & 26 & & & \\
\hline 422 & 34 & 22 & & & \\
\hline 380 & 33 & 21 & \multirow{2}{*}{70} & & \\
\hline 304 & 33 & 19 & & & \\
\hline
\end{tabular}

Value for each grid shown at Fig.6 and grid value based on interval value shown at Fig.7 Main grid significance with its neighbor has been examined by spatial analysis; Gery's and LISA correlation along with Gery's and LISA significance. The result shown at Fig.8, LISA Significance Map and Fig.9 Gery’s Significance Map.

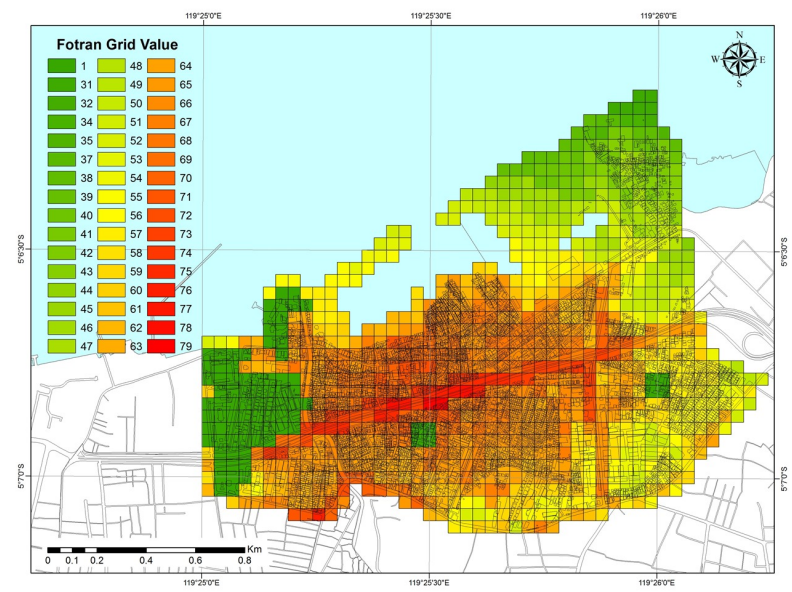

Figure 6. Map of Grids Value

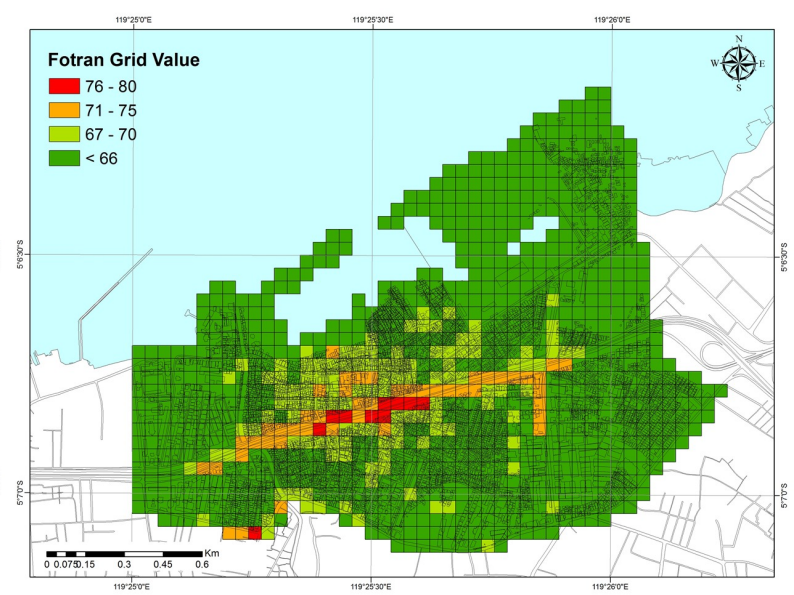

Figure 7. Map of Grids Value 


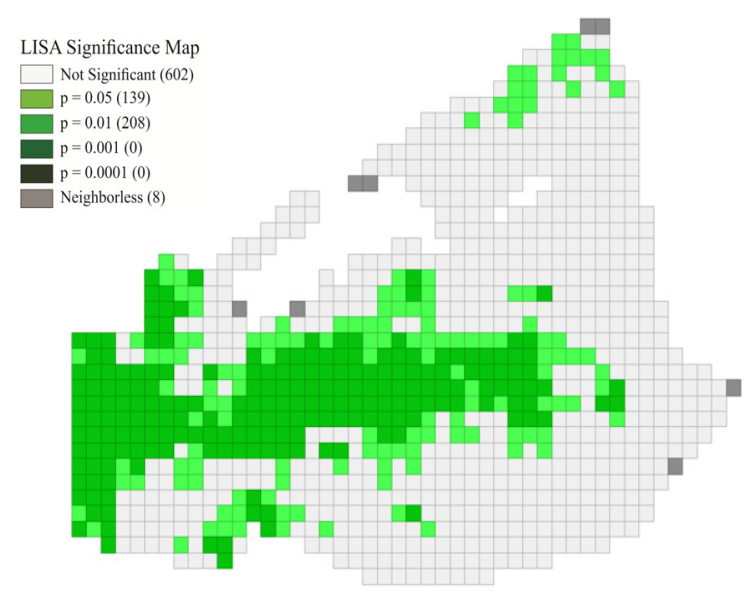

Figure 8. LISA Significance Map

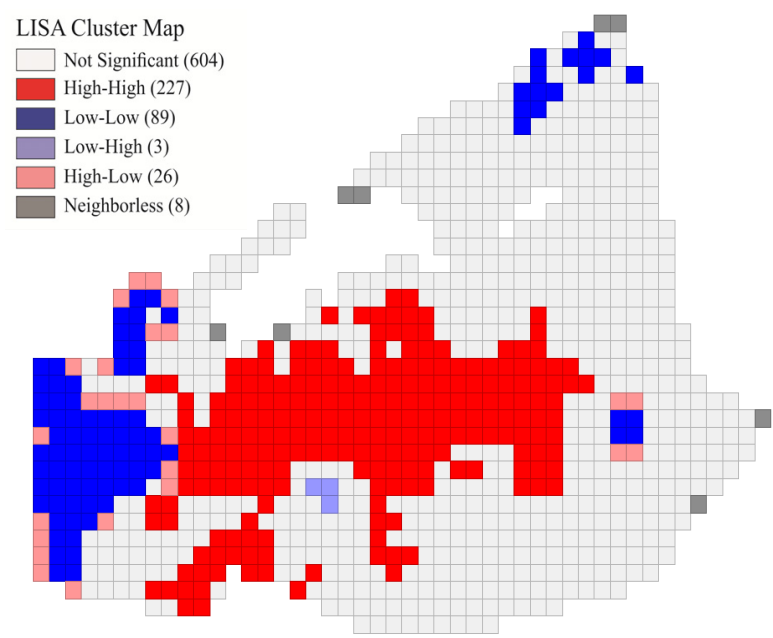

Figure 10. LISA Cluster Map

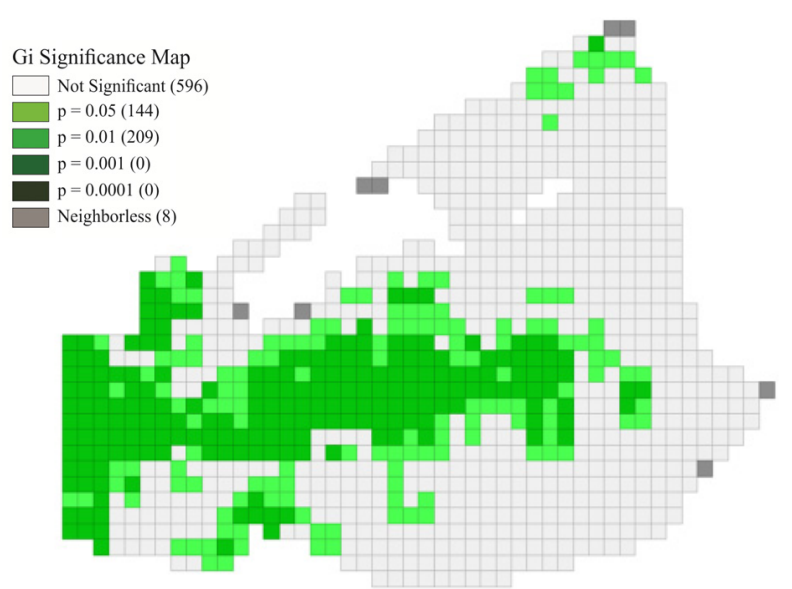

Figure 9. Gery's Significance Map

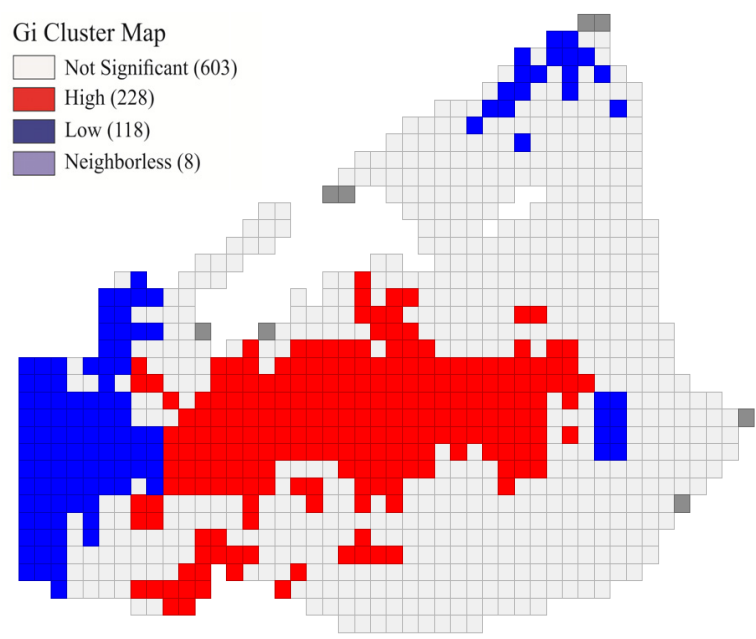

Figure 11. Gery’s Cluster Map

The Fig.10 and Fig.11 displays location of HH, HL, LL and LH clusters. Fig.12 in the following is a chart of frequency of value and number of grid distribution. The Fig.13 shows TOD location priority based on grid number and suitable grid value. Fig.14 in the following is location of coastal TOD potential at local port based on LISA and Gery's Cluster Map. Grid value and number of grid distribution from the result of spatial analysis processing can be seen at local port and its surroundings grid 584 and 585 with value 79 were selected as the first ranking followed by 542 and 581 with value 78 in the second, 541 , and 582 with value 77 in the third also 540 , 543,625 , with value 76 in the fourth. Those grids were the most potential to be the most suitable priority to develop suitable coastal TOD.

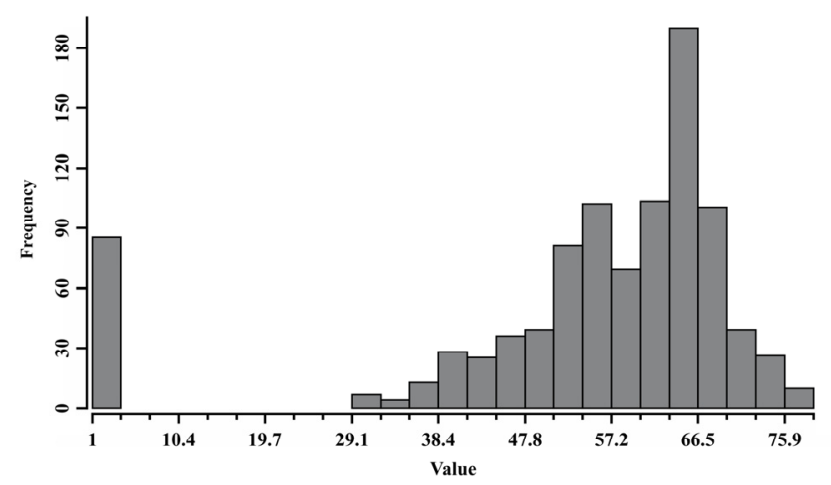

Figure 12. Chart of Value and Number Grid Distribution 


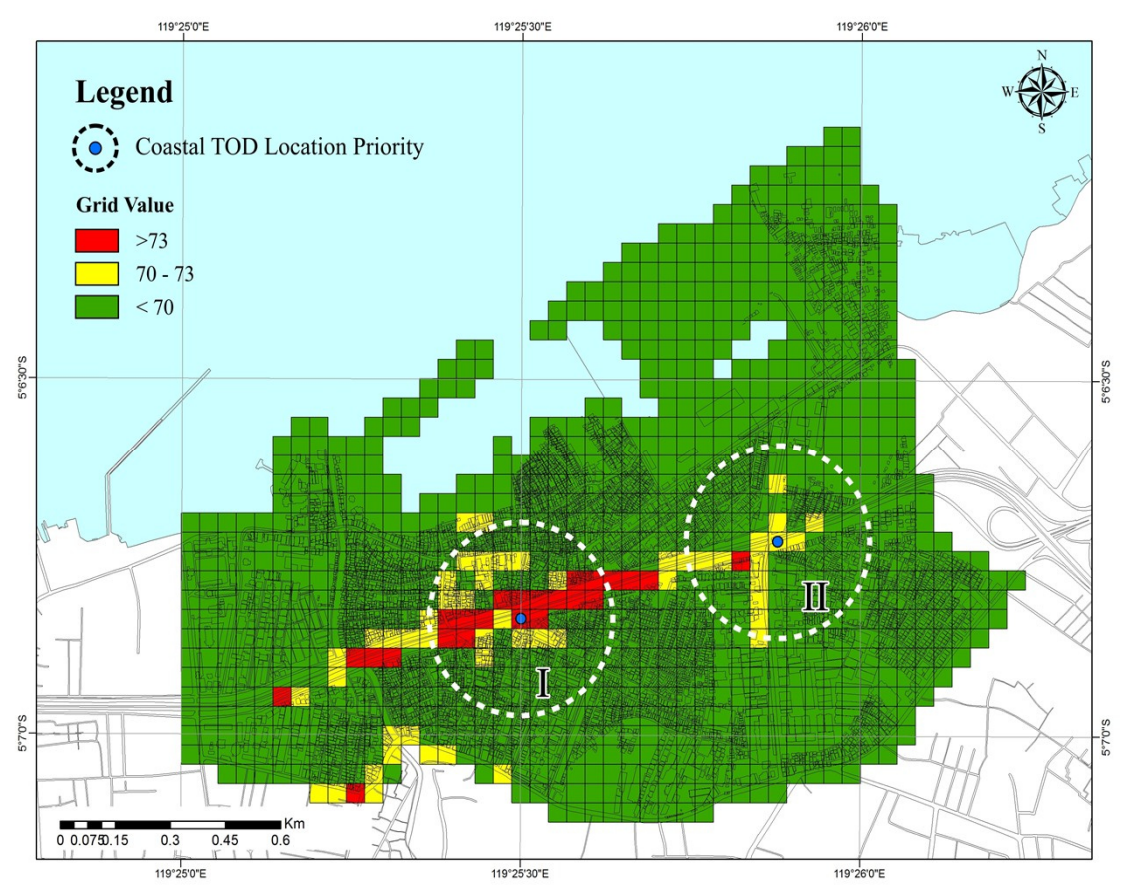

Figure 13. Map of potential coastal TOD development priority location

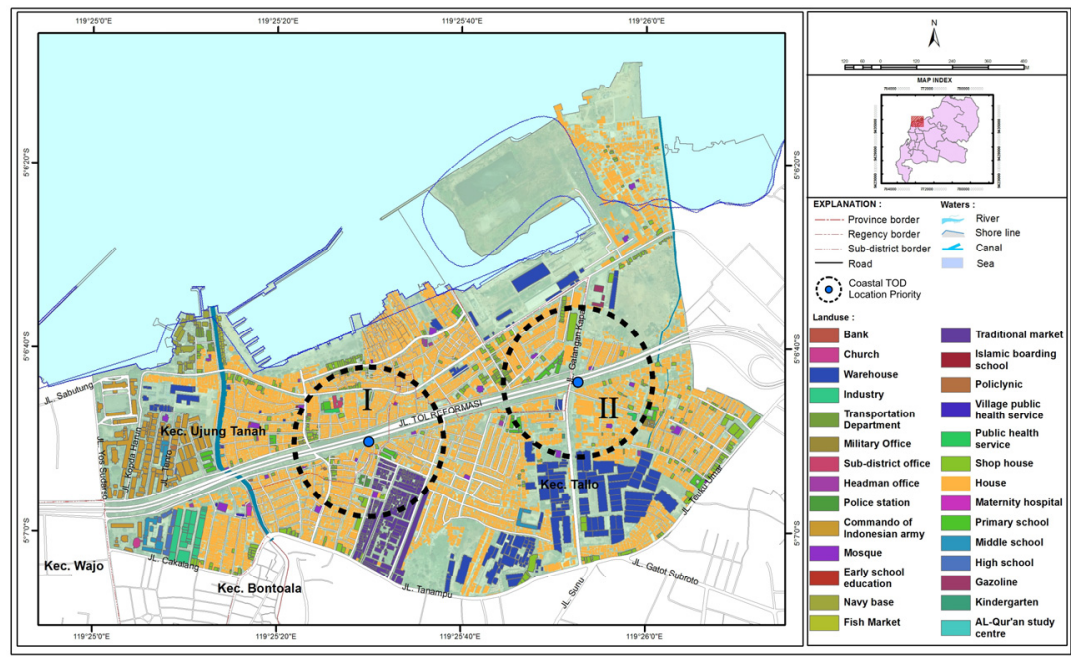

Figure 14. Map of Potential Coastal TOD Development location at local port based on spatial

Determination model of suitable TOD location development could eliminate redundancy of cost, time and travel distance of commuter and local society. It could be eliminated due to the availability of their needs within walking radius without using motorized vehicle

Within walking radius, mobility of shopped goods of commuter and local society from shopping centers or traditional market within TOD radius to the port and vice versa is no longer require motorized vehicle but using integrated and coordinated conveyor.

\section{Conclusions}

Spatial planning development Model of coastal TOD at local port area is a method to select and determine suitable location for coastal TOD. This was carried out in accordance with potential value (supporting and retarding ones) as well as travel distance of commuter and local society. It applied expert system and spatial analysis based on GIS. The accuracy for location of coastal TOD development value was determined by precision and perfection of certainty factor in expert system and neighborhoods value of the location in spatial analysis. 
Coastal TOD development is implemented vertically and integratedly for construction of building and public amenities in which its management should be integrated among stakeholders (government, entrepreneur, NGO and local society). Political policy and fund availability are the key to establish spatial planning of coastal TOD development at local port and he neighborhood.

This coastal TOD development model would eliminate redundancy of cost, time, and travel distance of commuter and local society in fulfilling their basic needs at the shore of Makassar. Operational and maintenance cost of the motorized vehicle could be reduced by optimizing mass transit, walking and cycling. In addition, coastal TOD development could be healthier, eco-friendly and sustainable.

\section{Acknowledgments}

This research could be finished because of active participation from many parties particularly to sir/madam professors, lecturers and students especially at Urban Planning and Design laboratory for their meaningful help.

\section{References}

Abdullah, L., \& Pang, J. Y. (2016). Application of Analytic Hierarchy Process for Assessing Sustainable Development among Underprivileged Communities. Journal of Sustainable Development, 9(5), 70-82.

Arnott, R., \& Inci, E. (2006). An Integrated model of downtown parking and traffic congestion. Urban Economics, 60 (traffic congestion, crossing for parking, and on street parking.), 418-442.

Balachandran, B. R., Cevero, R., Deakin, B., King, M., Mehndiratta, S., Nadal, L., . . Suzuki, H. (2014). TOD Standard v2.1. -, 1-76.

Briggs. (2007). Spatial Statistics. UT-Dallas GISC 6382.

Bruce, C. (2012). Transit-Oriented Development in China: Designing a new transit-oriented neighbourhood in Herxi New Town, Nanjing, Based on Hongkong Case Studies. -, Bleking Institute of Technology \& Nanjing Forestry University(Urban Design), 1-58.

Cervero, R., \& Guerra, E. (2013). Is a Half-Mile the Right Standard for TODs? Access 42, -(Design, Development, and Housing, Tools of the Trade: Practice, Measuring, and Models), 1-6.

Chakrabarti, S. (2015). The demand for reliable transit service: New evidence using stop level data from the Los Angeles Metro bus system. Journal of Transport Geography, 48, 154-164. http://dx.doi.org/10.1016/j.jtrangeo.2015.09.006

Davies, N. J., \& Weston, R. (2015). Reducing car-use for leisure: Can organised walking groups switch from car travel to bus and train walks? Journal of Transport Geography, 48, 23-29. http://dx.doi.org/10.1016/j.jtrangeo.2015.08.009

Elrayies, G. M. (2016). Rethinking Slums: An Approach for Slums Development towards Sustainability Journal of Sustainable Development, 9(6), 225-244.

Feudo, F. L. (2014). How to built an alternative to sprawl and auto-centric development model through a TOD scenario for the North-Pas-de-Calais region? Lesson from an integrated transportation-land use modelling. Elsevier Science Direct Transportation Research Procedia, 4(Integrated land-use and transport modelling: TOD, Tranus, urban sprawl, car dependency), 154-177.

Hasibuan, H. S., Soemardi, T. P., Koestoer, R., \& Moersidik, S. (2014). The Role of Transit Oriented Development in Constructing Urban Environment Sustainability, The Case of Jabodetabek, Indonesia. Procedia Environmental Sciences 20 (2014) 622, -(TOD), 620-631.

J.Stepner, M. (1992). City of San Diego Land Guidlines System -Transit Oriented Development Design Guidlines. 1-20.

Jain, A. (2015). Pune Awakes To Transit-Oriented Development. Pride Group Pune, 1-4.

Jin, S. X., Wang, J. J., \& Jiao, J. N. (2013). The Study in Diamond Interchange Traffic Organization. Procedia Social and Behavioral Sciences, 96(0), 591-598. http://dx.doi.org/10.1016/j.sbspro.2013.08.069

Khootdee, M., Singhirunnusorn, W., \& Sahachaisaeree, N. (2012). Effects of Green Open Space on Social Health and Behaviour of Urban Residents: A Case Study of Communities in Bangkok. Procedia - Social and Behavioral Sciences, 36(Accessibility, social health and behaviour.), 449-455.

Lester, D. (1990). Maslow's hierarchy of needs and personality. Personality and Individual Differences, 11(11), 1187-1188. http://dx.doi.org/10.1016/0191-8869(90)90032-M 
Litman, T. (2014). Transit Orianted Development Increases Value and Affordability. Planetizen, 1-3.

Lu, K., Zhu, Y., Li, Z., Singh, R. K., \& Nozaki, N. (2016). Dynamic Simulation Assessment of Environment Friendly Vehicles Introduction and Clean Energy Promotion Policy in China Journal of Sustainable Development, 9(5), 83-99.

Maslow, A. H. (1943). A Theory of Human Motivation. Psychological Review, 50.

Mateo-Babiano, I. (2016). Pedestrian's needs matter: Examining Manila's walking environment. Transport Policy, 45, 107-115. http://dx.doi.org/10.1016/j.tranpol.2015.09.008

Mpogole, H., \& Msangi, S. (2016). Traffic Congestion in Dar es Salaam: Implications for Workers' Productivity Journal of Sustainable Development, 9(6), 103-110.

Ngo, V. D. (2012). Identifying Areas for Transit-Oriented Development in Vancouver Using GIS. Journal of Geography, 6, 91-102.

Noltemeyer, A., Bush, K., Patton, J., \& Bergen, D. (2012). The relationship among deficiency needs and growth needs: An empirical investigation of Maslow's theory. Children and Youth Services Review, 34(9), 1862-1867. http://dx.doi.org/10.1016/j.childyouth.2012.05.021

Nur, N. K., Samang, L., Ramli, M. I., \& Hamid, S. (2016). Study of Modes Transformation Preferences of Private Transport Based on Travel Characteristics and user Behavior International Journal of Applied Engineering Research, 11, Number 22(transformation, modes of private transport, commuters, preferences, travel characteristics, user behavior ), 10766-10771.

P.Green, C., S.Heywood, J., \& Navarro, M. (2016). Traffic accidents and the London congestion charge. Journal of Public Economics, 133(Traffic accident, congestion costs and charge), 11-22.

Quinn, R., Adams, J. R., Dix, J. K., \& Bull, J. M. (1998). The Invincible (1758) site—an integrated geophysical assessment. The International Journal of Nautical Archaeology, 27(2), 126-138. http://dx.doi.org/10.1016/S1057-2414(98)80069-1

Rahul, \& Verma. (2013). Economic impact of non-motorized transportation in Indian cities. Elsevier, Volume 38(Non-motorized transport; Economic impacts; Role of non-motorized transport; Problems hindering non-motorized transport development), Pages 22-34.

Renne, J. L. (2008). Smart Growth and Transit Oriented Development at the State Level: Lesson from California, New Jersey, and Western Australia. Journal of Public Transportation, Vol. 11(Smart growth, TOD), 77-108.

Soltani, A., Hosseinpour, M., \& Hajizadeh, A. (2017). Urban Sprawl in Iranian Medium-sized Cities; Investigating the Role of Masterplans. Journal of Sustainable Development, 10, No.1(urban growth, sprawl, medium-sized city, masterplan), 122-131.

Vale, D. S. (2015). Transit-oriented development, integration of land use and transport, and pedestrian accessibility: Combining node-place model with pedestrian shed ratio to evaluate and classify station areas in Lisbon. Journal of Transport Geography, 45, 70-80. http://dx.doi.org/10.1016/j.jtrangeo.2015.04.009

Wey, W.-M. (2015). Smart growth and transit-oriented development planning in site selection for a new metro transit station in Taipei, Taiwan. Habitat International, 47, 158-168. http://dx.doi.org/10.1016/j.habitatint.2015.01.020

Zakaria, J., \& Ujang, N. (2015). Confort of Walking in the City Center of Kuala Lumpur. Elsevier, 170(Pedestrian confort, walking, accessibility, safety.), 642-652.

\section{Copyrights}

Copyright for this article is retained by the author(s), with first publication rights granted to the journal.

This is an open-access article distributed under the terms and conditions of the Creative Commons Attribution license (http://creativecommons.org/licenses/by/4.0/). 